\title{
Polarographic and Spectrophotometric Study of Lead Complexes with Diethanoldithiocarbamate
}

\author{
A.L.B. Marques ${ }^{\mathrm{a}}$, and G.O. Chierice ${ }^{\mathrm{b}}$ \\ a Departamento de Tecnologia Química, UFMA, Campus Universitário, Bacanga, \\ 65.080-040 São Luis - MA, Brazil \\ ${ }^{\mathrm{b}}$ Instituto de Física e Química de São Carlos, USP C.P. 369, S. Carlos - SP, Brazil
}

Received: June 4, 1997

\begin{abstract}
Foram estudados aspectos experimentais e teóricos sobre o comportamento do complexo de chumbo com dietanolditiocarbamato (DEDC), em solução. A reação ocorre através da formação de um precipitado amarelo, o qual é solúvel em excesso de ligante e alguns solventes polares. Os resultados das análises, elementar e gravimétrica, mostram uma relação estequiométrica de 1:2 (Pb:DEDC), comprovada nos estudos potenciométricos. A aplicação da equação de Lingane, nas formas estendida e simplificada, foi avaliada na determinação da constante de estabilidade global e do número máximo de coordenação, por Polarografia convencional. Os resultados indicam que são coordenados três ligantes, com uma constante de estabilidade, $\beta_{M L n}$, aproximadamente igual a $4 \mathrm{x}$ $10^{16}$. Estes resultados mostram boa concordância com outros prévios resultados, obtidos por potenciometria, para o mesmo sistema. Estudos cinéticos-espectrofotométricos foram conduzidos para avaliar a estabilidade do ligante puro e complexado em meio ácido.
\end{abstract}

Experimental and theoretical aspects concerning the behaviour of lead-dietanoldithiocarbamate complexes in aqueous solutions were studied. The reaction occurs through complexation and formation of a yellow precipitate, which is soluble in ligand excess and in some polar solvents. The results from elementary and gravimetric analyses show a stoichiometric relationship of 1:2 (Pb(II): DEDC). Some ambiguous interpretations have been clarified on the application in this system of Lingane's equation. Polarographic measurements were used to determine the coordination number ( $\cong 3.0)$ and overall formation constant $\beta_{\mathrm{MLn}}\left(\cong 4 \times 10^{16}\right)$, of the lead complexes with ammonium diethanoldithiocarbamate, which show a good agreement with previous potentiometric results for the same system. A kinetic-spectrophotometric study was carried out in order to establish the decomposition of these complexes in acid medium.

Keywords: lead, dithiocarbamate complexes, spectrophotometry, polarography, potentiometry

\section{Introduction}

Dithiocarbamate (dtc) is a class of compounds used extensively for extraction and spectrophotometric analysis of heavy metals ${ }^{1}$. Its high sensitivity and ability to form stable complexes over a wide $\mathrm{pH}$ range has resulted in numerous applications ${ }^{2-3}$. The properties of this ligand have been studied since the beginning of this century ${ }^{4}$. However, there is almost no information in the literature about the behaviour of the dithiocarbamates in aqueous or acid media. This compound possesses two sulfur atoms that allow it to form strong complexes ${ }^{5}$.

The stability constant of a complex is an important basic datum in analytical chemistry, particularly, for predicting interfering elements and for choosing optimum experimental conditions $^{6-8}$, such as $\mathrm{pH}$ and concentration. Apart from diethildithiocarbamate (DEDTC), diethanoldithiocarbamate (ADEDC) is one of the most commonly used forms of the ligand but very little is known about its complexes mainly in aqueous acid media. As a part of the continuing studies on the 
dithiocarbamate applications ${ }^{9-15}$ we report here the polarographic and spectrophotometric study of the reaction between lead (II) and ADEDC. Among the studies developed in our laboratory we describe results concerning as the adsorptive voltammetric behaviour ${ }^{14}$ of five dithiocarbamates ( $\left.\mathrm{dtc}_{\mathrm{s}}\right)$ at a static mercury drop electrode. In this work linear and cyclic wave forms were applied to perform measurements in open and close circuits. Results revealed that the radicals bonded to the nitrogen atom have a significant influence on the adsorptive properties of these ligands which decrease in the following series: phenyldtc $>$ benzyldtc $>$ ethylenebisdtc $>$ diethanoldtc $>$ diethyldtc. In an other study ${ }^{11}$ a voltammetric method, based on the adsorptive properties of the nickel-phenyldithiocarbamate complex, was proposed to determine traces of this metal in sea water. This study showed that only cobalt and zinc interfere, but not under the present conditions. After optimization of the instrumental and experimental parameters, the possibility of determining nickel (II) in sea water was evaluated. Optimal experimental conditions were found to be: $\mathrm{C}_{\text {phenyldtc }}=3 \times 10^{-3} \mathrm{M} ; \mathrm{E}_{\text {pre }}=-0.85 \mathrm{~V} ; \mathrm{pH}=9.2 ; \mathrm{t}_{\text {pre }}=3-5$ min. The limit of detection is $0.026 \mu \mathrm{g} / \mathrm{L}$ after $15 \mathrm{~min}$. and the results of precision and recovery were $4.39 \%$ and $101 \%$ $\pm 10 \%$, respectively. Other studies have been carried out on spectrophotometric potentialities ${ }^{9}$, and the crystal and molecular structure ${ }^{10}$ of copper and zinc complexes with diethanoldithiocarbamate, have been determined. In our recent study ${ }^{13}$ the lead(II)-ADEDC system was evaluated by potentiometric experiments using a lead electrode for the determination of solubility and stepwise constants. In the present work these same complexes have been examined in more detail and very good agreement has been found between the values determined in this work with the ${ }^{13}$ previous results. The overall stability constant of the lead (II) complex of diethanoldithiocarbamate in aqueous medium was determined by polarographic measurements using $\mathrm{NaNO}_{3}$ or $\mathrm{NaClO}_{4}$, as supporting electrolyte.

\section{Experimental}

\section{Equipment and reagents}

D.C. polarographic measurements were obtained with a PAR apparatus (model 174A), equipped with a conventional three electrode jacketed glass cell and an X-Y recorder (PAR model 0089). The $\mathrm{pH}$ was measured with a pH glass electrode (Metrohm, model AG9100) and a pH meter (Corning model 130). The spectra were recorded in the UV-visible region (Diode-Array HP, model $8451 \mathrm{UV}-$ Vis spectrophotometer) from $190 \mathrm{~nm}$ to $800 \mathrm{~nm}$ using $1 \mathrm{~cm}$ quartz cuvette. All analytical measurements were carried out at constant temperature $\left(25 \pm 0,1^{\circ} \mathrm{C}\right)$. The ionic strength in all solutions was supported with $0.1 \mathrm{M} \mathrm{NaClO}_{4}$ or $\mathrm{NaNO}_{3}$. The experiments were performed with analytical reagent grade chemicals, pure solvents and deionized water. The synthesis of the ADEDC was described elsewhere $^{16}$.

$\mathrm{Pb}\left(\mathrm{NO}_{3}\right)_{2}$ solutions were standardized gravimetrically $^{17}(0.1 \mathrm{M}$ and $0.5 \mathrm{M})$ and complexometrically ${ }^{18}(0.01$ $\mathrm{M})$ while ADEDC $0.1 \mathrm{M}$ was standardized potentiometrically using lead (II) as titrant solution and lead as working electrode $^{13}$.

\section{Polarographic procedure}

A solution containing ADEDC, supporting electrolyte, poliacrylamid, Triton-X-100 (maximum suppresser mixture) and water was deaerated with $\mathrm{N}_{2}$ for $20 \mathrm{~min}$. Then, a pre-deaerated aliquot of lead (II) solution was added. The polarograms were recorded in the following order: pure supporting electrolyte, after lead (II) addition, and after addition of each aliquot of ADEDC.

\section{Spectrophotometric procedure}

Spectrophotometric experiments were carried out considering the inverse order used in the polarographic experiments, i.e., addition of the aliquot of lead after the ADEDC ligand. In order to avoid different times of decomposition, the procedure used to prepare all complex solutions was carried out in such a way that the absorbances were measured two minutes after the addition of the dithiocarbamate.

\section{Results and Discussion}

\section{Spectrophotometric behaviour and preliminary experiments}

When the ligand was added to the metal solution, it was not possible to observe the reactivity of the $\mathrm{Pb}$-ADEDC system. Both, ligand and complex, absorb in the same spectral region, which shows only an increase of the ligand peak, despite the formation of the complex. In contrast, by adding metal to the ligand solution it was possible to see a clear change in the spectrum. If the ADEDC concentration is maintained constant and lead concentration is increased, from $1 \times 10^{-5}$ to $5 \times 10^{-5} \mathrm{M}$, two isosbestic points can be seen between 200 and $400 \mathrm{~nm}$. Outside this spectral range there is no change. The absorption spectra of the diethanoldithiocarbamate exhibit two peaks with maximum at $260 \mathrm{~nm}$ and $290 \mathrm{~nm}^{19-20}$, as shown in Fig. 1. The addition of lead ions only affects the first of these two peaks which corresponds to the sulfur absorption ${ }^{2,5}$. This could mean that the lead ion can support at least three dithiocarbamate ligands in order to justify its coordination number. In the present work the complexation reaction was investigated by polarography and spectrophotometry.

The complex is quickly formed but it is decomposed gradually with time as a result of oxidation or of the $\mathrm{pH}$ effect ${ }^{8}$. Therefore, despite being possible to observe a clear change in the two peaks of the spectra as a function of lead concentration, the shape of the new spectra does not show 


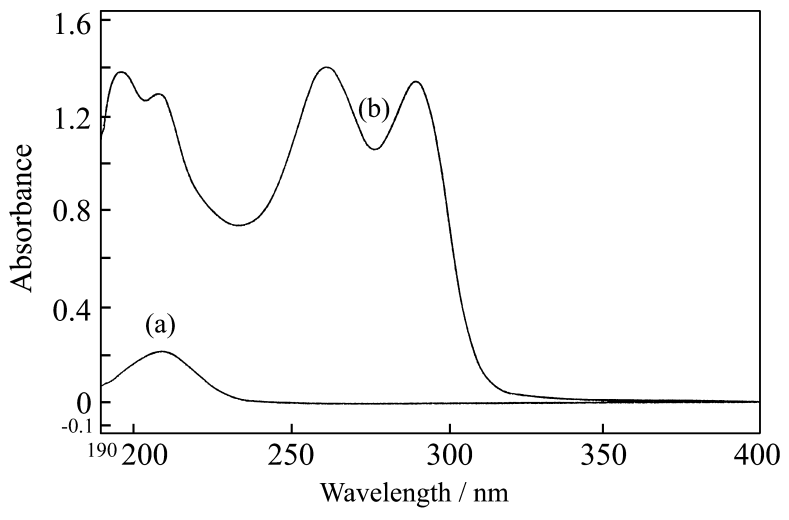

Figure 1. Absorption spectra of the lead (a) and ammonium diethanoldithiocarbamate with maximum absorption peaks at $260 \mathrm{~nm}$ and $290 \mathrm{~nm}$ (b): lead $=1 \times 10^{-5} \mathrm{M} ;$ ADEDC $=1 \times 10^{-4} \mathrm{M} ; 0.1 \mathrm{M} \mathrm{NaClO}_{4}$; $\mathrm{T}=25.0 \pm 0.1^{\circ} \mathrm{C}$.

a regular behaviour and that two isosbestic points could not be seen between 200 and $400 \mathrm{~nm}$. It can be seen that the absorbance increases at $260 \mathrm{~nm}$ while it decreases at 290 $\mathrm{nm}$. The most important parameters affecting the spectrophotometric behaviour are the reaction time and the order of reagent addition. However, this behaviour can be adequately adjusted to optimize the method. The order of reagent addition should be considered and the time between the dithiocarbamate addition (after lead) and the absorbance measurements should be the same for all solutions with different lead concentrations. Resolution is thus improved in such a way that two isosbestic points are obtained, as shown in Fig. 2. The extent to which the spectra change (Fig. 2), strongly depends on the narrowing ratio between lead and the diethanoldithiocarbamate ligand. For clear observation of the spectrophotometric reaction shown in Fig. 2, a fivefold excess of ligand to metal concentration was used. The complexation reaction has been ideally

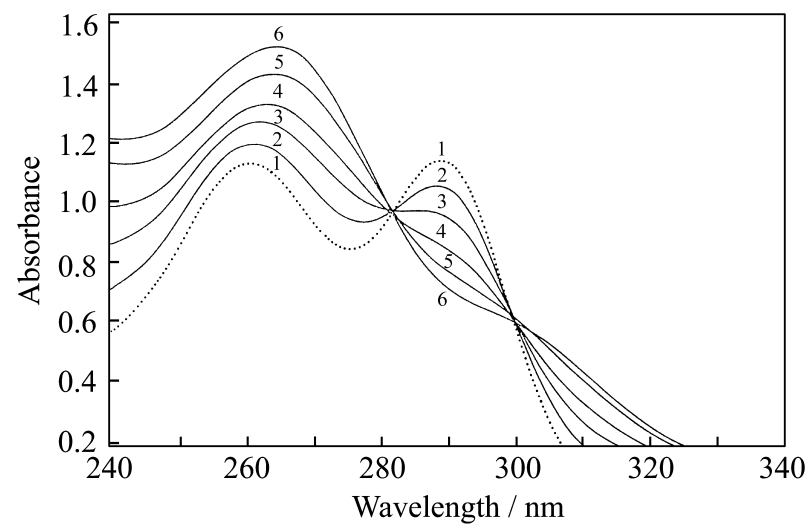

Figure 2. Spectra of the Pb-DEDCA system obtained in a solution containing a constant ligand concentration and increasing metal concentrations, obeying the time between the dithiocarbamate addition and the order (after lead), for all solutions with different lead concentrations: $\mu=$ $0,1\left(\mathrm{NaClO}_{4}\right) ; \mathrm{T}=25 \pm 0,1^{\circ} \mathrm{C} ; \mathrm{C}$ ADEDC $=1 \times 10^{-4} \mathrm{M} ; \mathrm{CLead}_{(\mathrm{II})}=1 \times 10^{-5}$ $\mathrm{M}(2), 2 \times 10^{-5} \mathrm{M}(3), 3 \times 10^{-5} \mathrm{M}(4), 4 \times 10^{-5} \mathrm{M}(5) 5 \times 10^{-5} \mathrm{M}$. observed by spectrophotometry by measuring the absorbance of a $1 \times 10^{-4} \mathrm{M}$ ADEDC solution. Thus, lead is added in the ideal concentration range between $1 \times 10^{-5} \mathrm{M}$ and 5 $\mathrm{x} 10^{-5} \mathrm{M}$.

The formation of a yellow precipitate was observed when lead and ADEDC were mixed in a 1:2 (Pb:ADEDC) ratio. The precipitate is soluble in ligand excess and in some polar solvents such as ethanol and acetone. The solubilization of the precipitate indicates the formation of a new species, that means, an other complex. The determination of lead by gravimetric and elementary analyses of the compound showed a good agreement with the previous proposed stoichiometry ${ }^{13}$, as shown in Table 1.

\section{Polarographic behaviour}

The polarographic behaviour of dithiocarbamates is very well known and the anodic waves of mercury complexes have been the object of many studies ${ }^{21-25}$. These anodic waves have limited the analytical application of many metal-dithiocarbamate complexes due to the narrow potential range. Lead (II) is one of the ions that can be studied by polarography in the presence of dithiocarbamate. A $1 \times 10^{-3} \mathrm{M}$ lead (II) solution in $0.1 \mathrm{M} \mathrm{NaNO}_{3}$, shows a DC polarographic wave at $400 \mathrm{mV}$ (vs. SCE). The complexation reaction has been investigated by measuring the potential shift $\left(\Delta \mathrm{E}_{1 / 2}\right)$ after adding the dithiocarbamate ligand to the lead (II) solution. To be able to characterize the equilibrium and to compare the present results with the ones obtained previously ${ }^{13}$, the polarographic measurements were carried out under identical experimental conditions as in the potentiometric method.

To avoid any precipitation, the polarographic behaviour of Pb-ADEDC system could only be studied in a solution containing a tenfold excess of ligand. Using this condition it was not possible to determine the successive stepwise constants by polarography. The lead concentration was maintained constant at $10^{-3} \mathrm{M}$. This value was chosen considering the polarographic sensitivity of the solution. A ligand concentration range of $10^{-2}$ to $10^{-1} \mathrm{M}$ was used due to the low solubility of the complex, especially in the 1:2 ( $\mathrm{Pb}: \mathrm{ADEDC})$ ratio.

Figure 3 shows the D.C. polarograms for the pure supporting electrolyte (a), after adding $10^{-3} \mathrm{M} \mathrm{Pb}\left(\mathrm{NO}_{3}\right)_{2}$ (b), and after adding $1 \times 10^{-2} \mathrm{M}$ ADEDC ligand (c). The complexation reaction has been investigated by measuring

Table 1. Gravimetric and microanalysis results for the $\mathrm{Pb}(\mathrm{DEDC}) 2$ salt.

\begin{tabular}{lcccc}
\hline Results & \multicolumn{3}{c}{ Elementary analysis } & $\begin{array}{c}\text { Gravimetric } \\
\text { results }\end{array}$ \\
\cline { 2 - 5 } & $\mathrm{C}$ & $\mathrm{N}$ & $\mathrm{H}$ & $\mathrm{Pb}$ \\
\hline Theoretical (\%) & 21.00 & 4.90 & 3.50 & 36.50 \\
Experimenal (\%) & 20.54 & 4.86 & 3.41 & 36.55 \\
\hline
\end{tabular}


the potential evolution of the polarographic wave of $1 \times 10^{-3}$ $M$ lead solution at increasing concentrations of ligand, from $1 \times 10^{-2} \mathrm{M}$ to $1 \times 10^{-1} \mathrm{M}$. The lead reduction potential is nearly $400 \mathrm{mV}$ less negative than that of the ADEDC ligand. The large negative potential shift of the lead wave

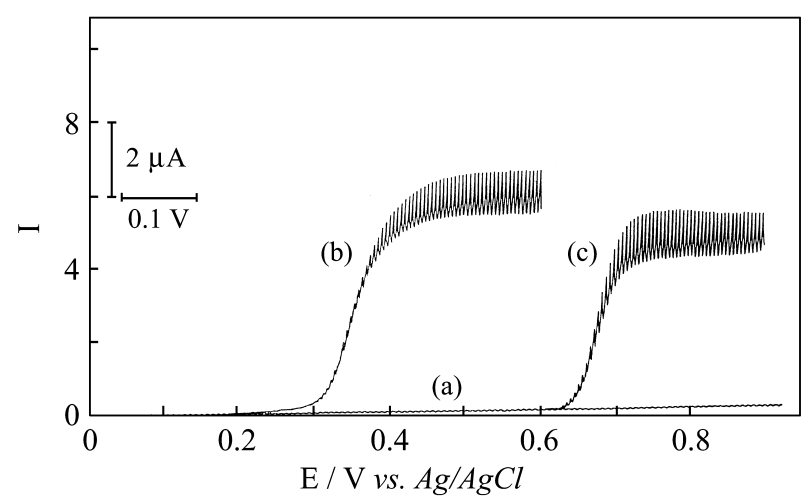

Figure 3. Typical D.C. polarograms of (a) pure supporting electrolyte, $0.1 \mathrm{M} \mathrm{NaNO}_{3}$; (b) $1 \times 10^{-3} \mathrm{M}$ lead(II) in $0.1 \mathrm{M} \mathrm{NaNO}_{3}$; (c) $1 \times 10^{-3} \mathrm{M}$ lead(II) $+1 \times 10^{-2} \mathrm{M}$ ADEDC in $0.1 \mathrm{M} \mathrm{NaNO}_{3}$. indicates the formation of complex between this ion and ADEDC and its high stability, as shown in Tables 2 and 3.

The polarograms obtained by polarographic reduction of the lead (II) in $0.1 \mathrm{M} \mathrm{NaNO}_{3}$ or $0.1 \mathrm{M} \mathrm{NaClO}_{4}$, are reversible and controlled by diffusion; the coefficient of charge transfer is very close to the unit (in $\mathrm{HCl} 0.1 \mathrm{M} \mathrm{HNO}_{3}$ and $\left.\mathrm{a}_{\mathrm{Pb}}=0.921\right)^{26}$. The logarithmic analysis of Lead(II) polarograms shows a linear dependence of $\log$ (id - i/i) vs. $\mathrm{E}_{\mathrm{dc}}$ (Fig. 4), the slope corresponds to a reversible reduction. Addition of the ligand to lead (II) solution in $0.1 \mathrm{M} \mathrm{NaNO}_{3}$ or $0.1 \mathrm{M} \mathrm{NaClO}_{4}$ provoke the shift of half-wave potentials leading to the reduction of this cation at more cathodic values (Fig. 3 and Tables 2 and 3). In the Pb-ADEDC system the reduction waves of the complexed ion is reversible and diffusion-controlled; the logarithmic analysis of the polarograms shows a linear dependence of $\log (\mathrm{id}-\mathrm{i} / \mathrm{i}$ ) $v s$. $\mathrm{E}_{\mathrm{dc}}$, (Fig. 5). Figure 6 shows that the half wave potential represented by $\Delta \mathrm{E}_{1 / 2}$ has a linear correlation with the ligand concentration, this proves that there is only one complex in the solution, the slopes of linear plots area in agreeement

Table 2. Variation of the potential ( $v$ s. $\mathrm{Ag} / \mathrm{AgCl} / \mathrm{NaCl}), \Delta \mathrm{E}_{1 / 2}$, diffusion current, and $\mathrm{pH}$ of a $1 \times 10^{-3} \mathrm{M}$ lead solution as a function of the ligand concentration in the presence of $0.1 \mathrm{M} \mathrm{NaNO}_{3}$.

\begin{tabular}{lcccccccccc}
\hline $\mathrm{C}_{\mathrm{ADEDC}}$ & $\Delta \mathrm{E}_{1 / 2}(\mathrm{mV})$ & $\mathrm{i}_{\mathrm{d}}(\mu \mathrm{A})$ & $\mathrm{pH}$ & $-\log \mathrm{C}_{\mathrm{L}}$ & {$[\mathrm{L}]_{1}$} & $-\log [\mathrm{L}]_{1}$ & {$[\mathrm{~L}]_{2}$} & $-\log [\mathrm{L}]_{2}$ & $\mathrm{a}_{\mathrm{L}} \mathrm{X} 10^{2}$ & $-\operatorname{logaL}$ \\
\hline 0.0208 & 319.55 & 5.82 & 7.94 & 1.6819 & 0.0181 & 1.7418 & 0.0183 & 1.7376 & 1.576 & 1.8022 \\
0.0256 & 327.25 & 5.62 & 8.04 & 1.5917 & 0.0229 & 1.6398 & 0.0231 & 1.6364 & 1.940 & 1.7121 \\
0.0304 & 332.25 & 5.82 & 8.10 & 1.5171 & 0.0277 & 1.5572 & 0.0279 & 1.5545 & 2.304 & 1.6374 \\
0.0352 & 334.60 & 6.08 & 8.15 & 1.4534 & 0.0325 & 1.4878 & 0.0327 & 1.4855 & 2.668 & 1.5740 \\
0.0400 & 342.40 & 5.70 & 7.90 & 1.3979 & 0.0373 & 1.4280 & 0.0375 & 1.4260 & 3.032 & 1.5183 \\
0.0512 & 352.30 & 5.67 & 7.91 & 1.2907 & 0.0485 & 1.3141 & 0.0487 & 1.3125 & 3.881 & 1.4111 \\
0.0608 & 356.80 & 6.00 & 7.91 & 1.2161 & 0.0581 & 1.2357 & 0.0583 & 1.2344 & 4.608 & 1.3364 \\
0.0704 & 359.95 & 5.65 & 7.98 & 1.1524 & 0.0677 & 1.1693 & 0.0679 & 1.1682 & 5.335 & 1.2727 \\
0.0800 & 365.50 & 5.60 & 7.99 & 1.0969 & 0.0773 & 1.1117 & 0.0775 & 1.1107 & 6.064 & 1.2172 \\
0.0896 & 370.10 & 5.86 & 7.99 & 1.0477 & 0.0869 & 1.0608 & 0.0871 & 1.0600 & 6.791 & 1.1680 \\
\hline
\end{tabular}

Table 3. Variation of the potential ( $v s$. $\mathrm{Ag} / \mathrm{AgCl} / \mathrm{NaCl}$ ), $\Delta \mathrm{E}_{1 / 2}$, diffusion current, and $\mathrm{pH}$ of a $1 \times 10^{-3} \mathrm{M}$ lead solution as a function of the ligand concentration in the presence of $0.1 \mathrm{M} \mathrm{NaClO}_{4}$.

\begin{tabular}{lcccccccccc}
\hline $\mathrm{C}_{\mathrm{ADEDC}}$ & $\Delta \mathrm{E}_{1 / 2}(\mathrm{mV})$ & $\mathrm{i}_{\mathrm{d}}(\mu \mathrm{A})$ & $\mathrm{pH}$ & $-\log \mathrm{C}_{\mathrm{L}}$ & {$[\mathrm{L}]_{1}$} & $-\log [\mathrm{L}]_{1}$ & {$[\mathrm{~L}]_{2}$} & $-\log [\mathrm{L}]_{2}$ & $\mathrm{a}_{\mathrm{L}} \mathrm{X} 10^{2}$ & $-\operatorname{logaL}$ \\
\hline 0.0208 & 316.9 & 5.800 & 7.88 & 1.6819 & 0.0179 & 1,7461 & 0.0181 & 1.7410 & 1.576 & 1.802 \\
0.0256 & 321.9 & 5.826 & 7.85 & 1.5917 & 0.0227 & 1.6431 & 0.0229 & 1.6391 & 1.940 & 1.7121 \\
0.0304 & 329.3 & 5.652 & 7.89 & 1.5171 & 0.0275 & 1.5599 & 0.0227 & 1.5566 & 2.304 & 1.637 \\
0.0352 & 334.3 & 5.572 & 7.87 & 1.4534 & 0.0323 & 1.4902 & 0.0325 & 1.4874 & 2.668 & 1.5740 \\
0.0400 & 340.4 & 5.760 & 7.88 & 1.3979 & 0.0371 & 1.4301 & 0.0373 & 1.4276 & 3.032 & 1.518 \\
0.0512 & 348.9 & 5.760 & 7.88 & 1.2997 & 0.0483 & 1.3156 & 0.0485 & 1.3137 & 3.881 & 1.4111 \\
0.0608 & 351.9 & 5.800 & 7.87 & 1.2161 & 0.0579 & 1.2370 & 0.0581 & 1.2354 & 4.608 & 1.3364 \\
0.0704 & 361.6 & 5.740 & 7.92 & 1.1524 & 0.0675 & 1.1704 & 0.0677 & 1.1691 & 5.336 & 1.2727 \\
0.0800 & 365.8 & 5.592 & 7.89 & 1.0969 & 0.0771 & 1.1127 & 0.0773 & 1.1115 & 6.064 & 1.2172 \\
\hline
\end{tabular}




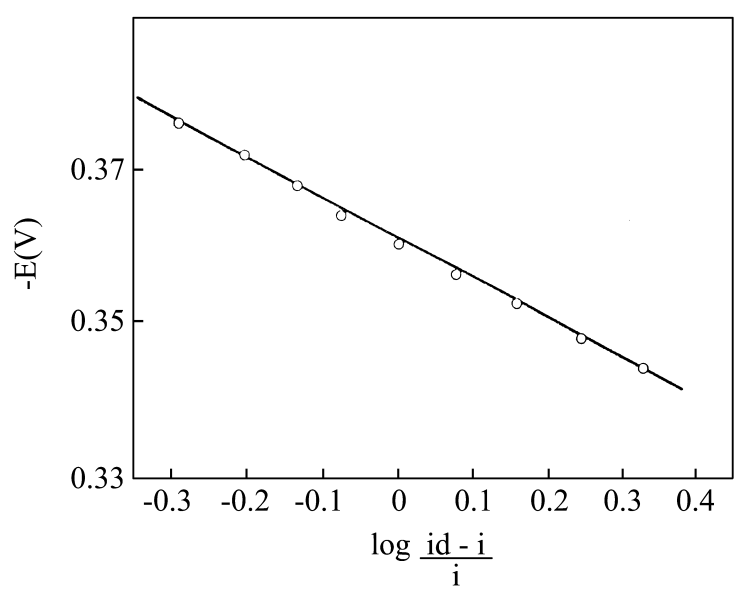

Figure 4. Linear dependence of $\log (\mathrm{id}-\mathrm{i} / \mathrm{i})$ vs. Edc for the lead(II) solution in $0.1 \mathrm{M} \mathrm{NaNO}_{3}$. Other conditions as described in Experimental section.

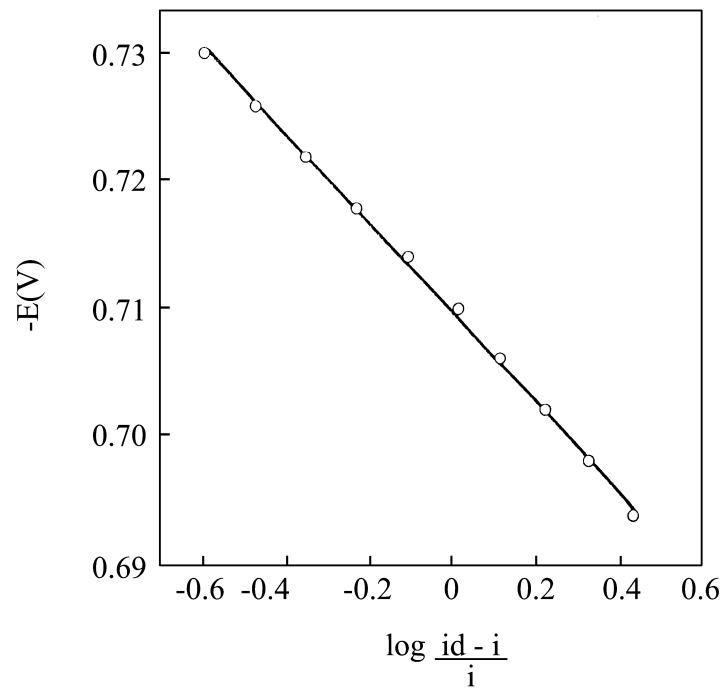

Figure 5. Linear dependence of $\log (\mathrm{id}-\mathrm{i} / \mathrm{i}) v s$. $\mathrm{E}_{\mathrm{dc}}$ for the complex in $0.1 \mathrm{M} \mathrm{NaNO}_{3}$. Other conditions as described in Experimental section.

with a 1:1 type complex. The half wave potentials of the Lead(II), free and complexed, were determined from the intercepts of the straight lines of Figs. 4 and 5.

\section{Determination of coordination number and overall stability constants}

The following equation (Lingane's simplified equa$\operatorname{tion}^{27-28}$ ) was used to calculate the coordination number and the overall stability constants of the complexes formed in the system studied.

$$
\Delta \mathrm{E}_{1 / 2}=\frac{0.0591}{\mathrm{n}} \log \beta_{\mathrm{MLn}}+\mathrm{N} \frac{0.0591}{\mathrm{n}} \log \mathrm{C}_{\mathrm{L}}
$$

The results obtained using this equation $\left(\log \beta_{\mathrm{MLn}}=\right.$ 15.4 in $\mathrm{NaNO}_{3}$ and $\log \beta_{\mathrm{MLn}}=15.6$ in $\mathrm{NaClO}_{4}$ ) area not in agreement with previous results ${ }^{13}$ obtained for the same system. Thus, a reevaluation was carried out in order to

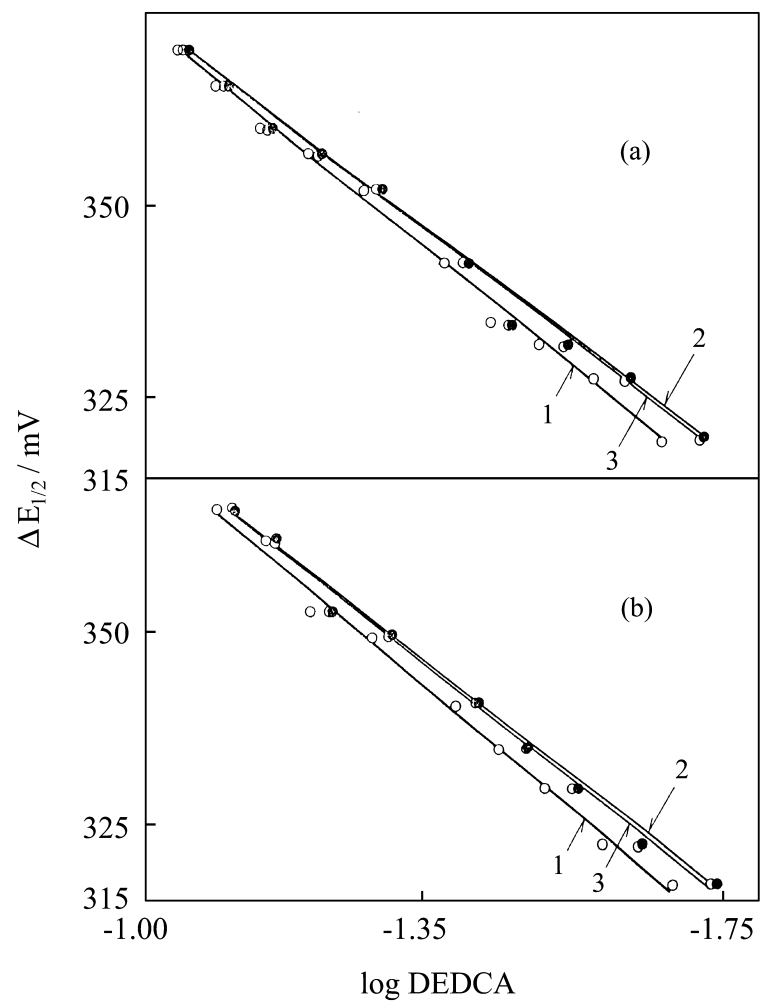

Figure 6. Linear dependence of halfwave potential $\left(\Delta \mathrm{E}_{1 / 2}\right)$ on the ligand concentration (ADEDC), in $0.1 \mathrm{M} \mathrm{NaNO}_{3}$ (a) and $0.1 \mathrm{M} \mathrm{NaClO}_{4}$ (b). (1): $\left(\Delta \mathrm{E}_{1 / 2}\right) \times \log \mathrm{C}_{\mathrm{L}}$; (2): $\left(\Delta \mathrm{E}_{1 / 2}\right) \times \log [\mathrm{L}]_{1} ;(3):\left(\Delta \mathrm{E}_{1 / 2}\right) \times \log [\mathrm{L}]_{2}$. Data from Tables 2 and 3. Other conditions as described in the Experimental section.

validate the approximations between the extended Lingane's Eq. (2) and Eq. (1).

$$
\Delta \mathrm{E}_{1 / 2}=\frac{0.0591}{\mathrm{n}} \log \left[\frac{\mathrm{I}_{\mathrm{MLn}}}{\mathrm{I}_{\mathrm{M}}}\right]\left[\frac{\mathrm{f}_{\mathrm{M}} \mathrm{f}_{\mathrm{L}}^{\mathrm{n}}}{\mathrm{f}_{\mathrm{MLn}}}\right]\left[\beta_{\mathrm{MLn}} \mathrm{C}_{\mathrm{L}}^{\mathrm{n}}\right]
$$

The Eq. (2), was first obtained by Heyrovsky and Ilkovic $^{29}$ and later by Van Stackelberg and Freyhold ${ }^{30}$ as well as Lingane ${ }^{31}$. This equation can be applied only when one complex is present and its stability is relatively high.

The Lingane treatment for the formation of simple complexes allows the calculations of overall stability constant and the maximum coordination number, where $\mathrm{C}_{\mathrm{L}}$ is the analytical ligand concentration, $\Delta \mathrm{E}_{1 / 2}$ is the difference in the half-wave potential when $\mathrm{C}_{\mathrm{L}}=0$ and when $\mathrm{C}_{\mathrm{L}} \neq 0$, $\mathrm{I}_{\mathrm{M}}$ and $\mathrm{I}_{\mathrm{MLn}}$ are the corresponding diffusion current constants and $\beta_{\mathrm{MLn}}$ values are the stoichiometric overall stability constants at constant ionic strength.

\section{Validity of the aproximations}

Equation (2), named the extended Lingane's equation, can be simplified to Eq. (1), considering $\mathrm{C}_{\mathrm{L}}=[\mathrm{L}] ; \mathrm{I}_{\mathrm{M}}=\mathrm{I}_{\mathrm{MLn}}$ and $\left(\mathrm{f}_{\mathrm{M}} \cdot \mathrm{f}_{\mathrm{L}}{ }^{\mathrm{n}} / \mathrm{f}_{\mathrm{MLn}}\right)=1,0$.

To verify the validity of the approximation $\mathrm{C}_{\mathrm{L}}=[\mathrm{L}]$, the correct correlation between $\Delta \mathrm{E}_{1 / 2} \times \log [\mathrm{L}]$ was evalu- 
ated by successive approximations between Eq. (1) and the known equation $[\mathrm{L}]=\mathrm{C}_{\mathrm{L}}-\mathrm{N}^{\prime} \mathrm{C}_{\mathrm{M}}{ }^{32}$. The slope of the Eq. (1) $\left(\Delta \mathrm{E}_{1 / 2} \times \log \mathrm{C}_{\mathrm{L}}\right)$ was determined considering, firstly, $\mathrm{C}_{\mathrm{L}}$ and later $[\mathrm{L}]$, in this equation. The iterative cycle of approximations was repeated until the convergence of the results (constant values) for $\mathrm{N}$ and $\log \beta_{\mathrm{MLn}}$ (Tables 2 and 3 and Fig. 6). Errors of $6 \%$ for $\mathrm{N}$ were considered good results and $0.98 \%$ for $\log \beta_{\mathrm{MLn}}$, insignificant. Therefore, the approximations were considered valid.

In the second approximation the diffusion current was evaluated by substituting the values of $\mathrm{I}_{\mathrm{MLn}}$ and $\mathrm{I}_{\mathrm{M}}$ (5.782 $\mu \mathrm{A}$ and $7 \mu \mathrm{A}$, respectively) in Eq. (2). In this case, $\mathrm{C}_{\mathrm{L}}$ was used instead of activity. The error obtained was $0.54 \%$ for $\log \beta_{\mathrm{MLn}}$ and no error was found for $\mathrm{N}$.

To eliminate $\left(\mathrm{f}_{\mathrm{M}} \cdot \mathrm{f}_{\mathrm{L}}{ }^{\mathrm{n}} / \mathrm{f}_{\mathrm{MLn}}\right)$ in the Eq. (2), the ionic strength and the concentrations of the species should be considered. The experiments were carried out in an ionic strength of $0.1 \mathrm{M}$ and the activity coefficient of the ligand $\left(f_{L}\right)$ was found to be 0.758 . Considering that the ideal value for $\left(f_{M} \cdot f_{L}{ }^{n} / f_{M L n}\right)$ ratio should be 1.0, this approximation was not recommended. In order to support this conclusion, Lingane's equation was applied considering the activity instead of the ligand concentration. The following results were obtained: $\mathrm{N}=2.68\left(\mathrm{NaNO}_{3}\right)$ and $2.86\left(\mathrm{NaClO}_{4}\right)$; $\log$ $\beta_{\mathrm{MLn}}=15.80\left(\mathrm{NaNO}_{3}\right)$ and $15.92\left(\mathrm{NaClO}_{4}\right)$. The comparison between these values and the one obtained using $\mathrm{C}_{\mathrm{L}}$, reveals that there was no difference for the coordination number. However, the error was $3 \%$ for $\log \beta_{M L n}$, and we concluded that Lingane's equation should be used in the extended form, and that approximations are not valid. Therefore, the correct values for $\mathrm{N}$ and $\beta_{\mathrm{MLn}}$ were obtained from a plot of $\Delta \mathrm{E}_{1 / 2} v s$. ligand activity, as shown in Fig. 7.

Finally, to check the results obtained in the present work, the constant $\left(\log \beta_{\mathrm{MLn}}\right)$ and the coordination number $(\mathrm{N})$ of the same system were also determined using a lead electrode developed in our laboratory ${ }^{13}$. The results are presented in Table 4. Table 5 gives a general comparison between the polarographic and potentiometric methods.
Kinetic evaluation on the stability of diethanoldithiocarbamates

The ideal concentration range for lead $\left(1 \times 10^{-5}\right.$ to $5 \mathrm{x}$ $\left.10^{-5} \mathrm{M}\right)$ to observe spectrophotometrically its reaction with ADEDC, corresponds to a molar ratio between 10 and 2, for a constant ligand concentration of $1 \times 10^{-4} \mathrm{M}$. This range is very short to permit a comparison among the spectrophotometric, polarographic and potentiometric results performed in the present work. The corresponding spectral variation for this concentration range shows high dependence of kinetic factors, since the two isosbestic points are a function of the time control. Linear dependence of the absorbance on metal concentration also depends on time control of the reaction.

The kinetic decomposition rate was investigated in a solution containing $10^{-4} \mathrm{M}$ ADEDC with ionic strength 0.1 $\mathrm{M}\left(\mathrm{NaClO}_{4}\right)$ at $\mathrm{pH} 4.0$ (acetate buffer). Figure 8 shows the fast decomposition of the ADEDC in acid media, as reported in the literature ${ }^{20}$. The apparent rate constant $\left(\mathrm{K}_{\mathrm{obs}}\right)$ was determined as being $0.37 \mathrm{~min}^{-1}$ with a $\mathrm{t}_{1 / 2}$ of approximately 2 min, as shown in Fig. 9.

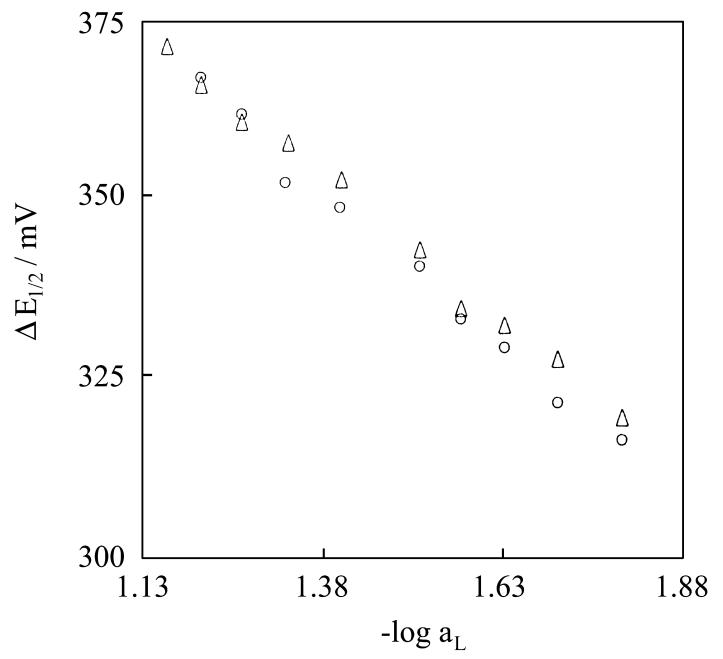

Figure 7. Linear dependence of half wave potential $\left(\Delta \mathrm{E}_{1 / 2}\right)$ on the ligand activity (ADEDC), in $0.1 \mathrm{M} \mathrm{NaNO}_{3}$ (a) and $0.1 \mathrm{M} \mathrm{NaClO}_{4}$ (b). Other conditions as described in the Experimental section.

Table 4. Potentiometric data referent the determination of $\mathrm{N}$ e $\beta_{\mathrm{n}}(0.1 \mathrm{M} \mathrm{NaNO})$ using extended Lingane's equation and ligand activity.

\begin{tabular}{lcccc}
\hline $\mathrm{C}_{\text {ADEDCX } 10^{4}(\mathrm{M})}$ & $\Delta \mathrm{E}(\mathrm{mV})$ & $-\log \mathrm{ADDDC}_{\text {A }}$ & $\mathrm{a}_{\text {ADEDCX10 }}$ & -logaADEDC \\
\hline 5.0 & 194.5 & 3.3010 & 3.79 & 3.421 \\
5.5 & 200.5 & 3.2596 & 4.17 & 3.380 \\
6.0 & 202.9 & 3.2218 & 4.55 & 3.342 \\
8.0 & 214.8 & 3.0969 & 6.06 & 3.217 \\
12.0 & 230.7 & 3.9208 & 9.10 & 3.041 \\
17.5 & 246.0 & 3.7569 & 13.26 & 2.877 \\
25.0 & 254.7 & 3.6020 & 18.95 & 2.722 \\
50.0 & 277.0 & 3.3010 & 37.90 & 2.421 \\
80.0 & 290.5 & 3.0969 & 60.64 & 2.217 \\
\hline
\end{tabular}


Table 5. General results of the determination of $\mathrm{N}$ e $\beta_{\mathrm{n}}$ for the Pb-ADEDC system.

\begin{tabular}{|c|c|c|c|c|}
\hline \multirow{3}{*}{ Data } & \multirow{2}{*}{\multicolumn{2}{|c|}{$\begin{array}{c}\text { Polarography } \\
\text { Lingane's Method }\end{array}$}} & \multicolumn{2}{|c|}{ Potentiometry } \\
\hline & & & \multirow{2}{*}{$\begin{array}{c}\text { Lingane's Method } \\
\left(\mathrm{NaClO}_{4}\right) \\
\end{array}$} & \multirow{2}{*}{$\begin{array}{c}\text { Leden's Method } \\
\left(\mathrm{NaClO}_{4}\right)\end{array}$} \\
\hline & $\left(\mathrm{NaNO}_{3}\right)$ & $\left(\mathrm{NaClO}_{4}\right)$ & & \\
\hline $\mathrm{N}$ & 2.7 & 2.9 & 2.7 & 2.9 \\
\hline \multirow{2}{*}{$\log \beta_{\mathrm{N}}$} & $15.80^{*}$ & $15.92 *$ & $15.91 *$ & \multirow{2}{*}{16.62} \\
\hline & $16.11 * *$ & $16.28 * *$ & $16.27 * *$ & \\
\hline
\end{tabular}

* simple Lingane's Equation.

** complete Lingane's Equation.

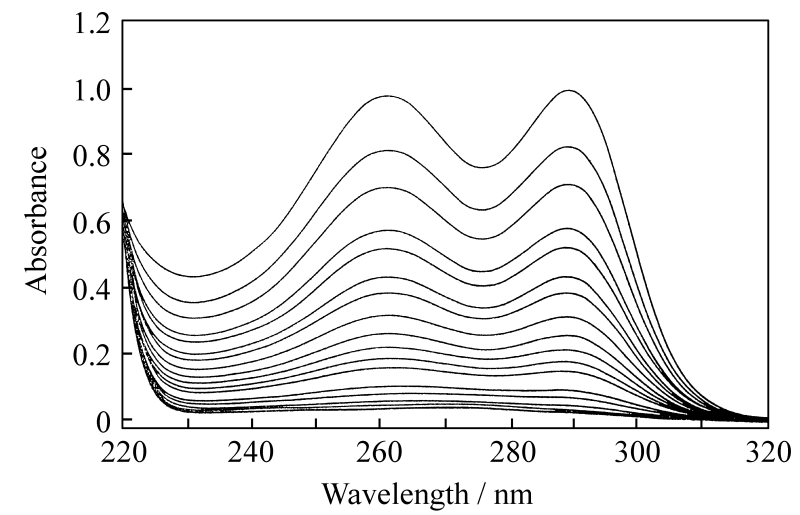

Figure 8. Spectra referent the ADEDC decomposition in acid media: $\mathrm{pH}$ $=5.0$ (acetate buffer); $\mathrm{T}=25 \pm 0.1^{\circ} \mathrm{C}$.

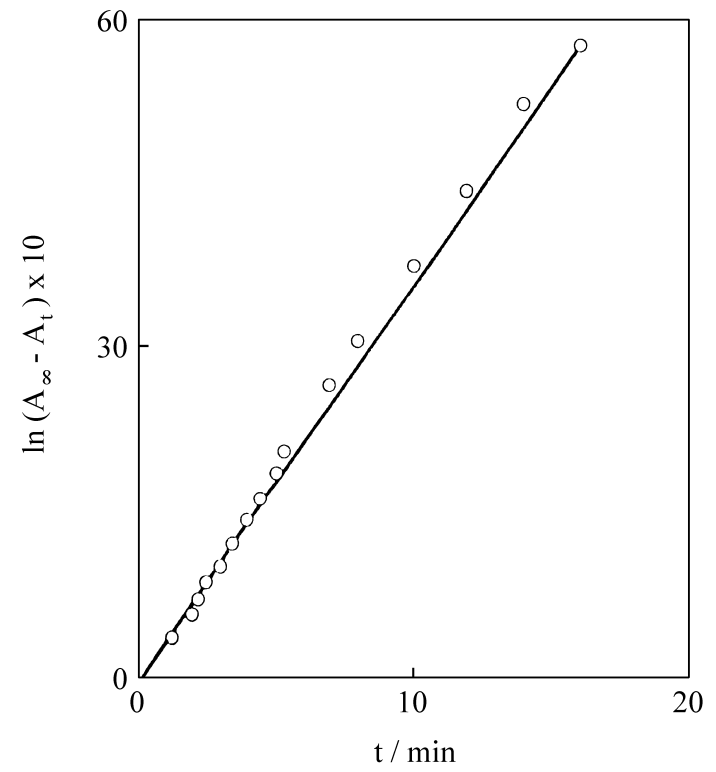

Figure 9. Linear dependence of $\ln \left(\mathrm{A}_{\omega}-\mathrm{A}_{\mathrm{t}}\right)$ as a function of the time, according to the determination of $\mathrm{k}_{\mathrm{obs}}$ and $\mathrm{t}_{1 / 2}$ for the decomposition reaction of ADEDC at $\mathrm{pH}$ 5.0.

The same study was carried out at $\mathrm{pH} 8.0$ and the ADEDC compound presented, under these conditions, a half life time of $2.26 \mathrm{~h}$, and only after eleven hours, the decomposition reached $90 \%$. The kinetic behaviour was
Table 6. Spectrophotometric data on the stability (decomposition) of the lead complexes of diethanoldithiocarbamates. $\mu=0.1\left(\mathrm{NaClO}_{4}\right)$; $\mathrm{T}=25 \pm 0.1{ }^{\circ} \mathrm{C}$.

\begin{tabular}{lcc}
\hline Abs $(262 \mathrm{~nm})$ & $\mathrm{t}(\mathrm{min})$. & Decompositon $(\%)$ \\
\hline 1.3150 & 1.24 & - \\
1.2920 & 3.00 & 1.53 \\
1.2733 & 5.00 & 3.05 \\
1.2481 & 10.00 & 4.73 \\
1.2346 & 15.00 & 6.10 \\
1.2241 & 20.00 & 6.87 \\
1.2155 & 25.00 & 7.63 \\
1.2083 & 30.00 & 7.78 \\
1.2021 & 35.00 & 8.24 \\
1.1966 & 40.00 & 9.16 \\
1.1899 & 45.00 & 9.23 \\
1.1849 & 50.00 & 9.92 \\
1.1791 & 55.00 & 10.00 \\
1.1737 & 60.00 & 10.68 \\
\hline
\end{tabular}

also evaluated for the lead complex and the results can be seen in Table 6. According to the high stability of the complex, its decomposition was considered slow $(10 \%$, at $\mathrm{pH} 8.0$ during approximately one hour of reaction) when compared to the ligand under the same conditions (50\% of decomposition after $2.26 \mathrm{~h}$ of reaction). These results show a very good agreement with the high stability constant of the system, studied in the present work.

\section{Conclusion}

This work presents a polarographic study of the $\mathrm{Pb}-\mathrm{AD}$ EDC system in aqueous media. The results indicate that the complex can only be polarographically studied after addition of a mixture of maximum suppreser solution containing Triton-X-100 and polyacrylamide. Under these conditions, $N$ (3.0) and $\log \beta_{\text {MLn }}$ (16.0) were determined, after evaluation of all possible Lingane's equation approximations. According to the results and evaluations carried out in this work it was observed that the Lingane's equation may be used in the extended form, without considering any approximations. A complete graphical and numerical calculation of the extended Lingane's equation shows its 
importance in the determination of the coordination number and overall stability constant of this complex. The present evaluation of the Lingane's equation shows that it is not always possible to use the simplified form in order to avoid the inherent statistical erros.

\section{Acknowledgment}

The authors gratefully acknowledge financial support from FAPESP, a fellowship from CAPES. Helpful discussions with Dr. O.E.S. Godinho, Dr. M.T. Grassi and Dr. M.M.K. Takiyama are also acknowledged.

\section{References}

1. Ovenston, T.C.J.; Paker, C.A. Anal. Chim. Acta 1950, 4, 135.

2. Thorn, G.D.; Ludwig, R.A. The Dithiocarbamates and Related Compounds, Elsevier Publishing Company, Amsterdam, 1962, 298p.

3. Magee, R.J.; Hill, J.O. The Analytical Chemistry of Metal Dithiocarbamate Complexes. Reviews in Anal. Chem. 1985, VIII 5-72.

4. Delepine, M. Compl. Rend. 1907, 144, 1125.

5. Hulanicki, A. Talanta, 1967, 14, 1371.

6. Inczedy, J. In Analytical Applications of Complex Equilibrium, J. Tyson (translated ed.), Ellis Horwood, 1976.

7. Ringbom, A. Complexation in Analytical Chemistry. Wiley, New York, 1963.

8. Sillen, L.G.; Martell, A. Stability Constants of MetalIon Complexes. The Chemical Society, London, 1964.

9. Marques, A.L.B., and Chierice G.O. Química Nova 1990,13 (2), 133.

10. Marques, A.L.B.; Chierice, G.O.; Gambardella, A.M.; Santos, R. Química Nova 1990, 13 (2), 125.

11. Marques, A.L.B.; Chierice, G.O. J. Braz. Chem. Soc. 1993, 4 (1), 17.

12. Marques, A.L.B.; Chierice, G.O. Química Nova 1991, $14(4), 30$.
13. Marques, A.L.B.; Chierice, G.O. An. Assoc. Bras. Quím. 1998, 47 (2) 85.

14. Breviglieri, S.T.; Cavalheiro, E.T.G.; Chierice, G.O. Polyedron 1996, 15 (5-6),839.

15. Gríolli, T.M.; Cavalheiro, E.T.G.; Gomes Neto, J.A.; Chierice, G.O. J. Sol. Chem. 1994, 23 (7) 543.

16. Haas, W.; Schwarz, T. Mikrochim. Acta 1963, $2,253$.

17. Vogel, A.I. Análise Inorgânica Quantitativa, 4a. ed. Guanabara Dois, RJ, 1981.

18. Manual da Merck. Métodos Complexométricos de Valoracion con Titriplex, 3a. ed., E. Merck, Darmstadt.

19. Smith, R.M.; Hurdley, T.G. Anal. Chim. Acta 1984, 166, 271.

20. King, J.L.; Fritz, J.S. Anal. Chem. 1985, 57, 1016.

21. Randle, T.H.; Cardwell, T.J.; Magee, R. J. Aust. J. Chem. 1975, 28, 21.

22. Budnikov, G.K.; Ulakhovich, N.A. Comunication 1. Zh. Anal. Khim. 1973, 28 (03), 448

23. Budnikov, G.K.; Toropova, V.F.; Ulakhovich, N.A.; Viter, I.P. Comunication 5. Zh. Anal. Khim. 1975, 30(11), 2120.

24. Budnikov, G.K.; Toropova, V.F.; Ulakhovich, N.A.; Medyantseva, E.P.; Frolova, V.P. Zh. Anal. Khim. 1977, 32(2), 212.

25. Randle, T.H.; Cardwell, T.J.; Magee, R. J. Aust. J. Chem. 1976, 29, 85.

26. Luca, C.K.; Azab, H.A.; Tanase, I. A. Anal. Letters, 1985, 18 (A4), 449.

27. Lingane, J. J. Chem. Rev. 1941, 29, 1.

28. Crow, D.R. Polarography of Metal Complexes. Academic Press, London, N.Y., 1969.

29. Heyrovsky, J.; Ilkovic, D. Coll. Czech. Chem. Commun. 1935, 7, 198.

30. Stackelberg, M.V.; Freyhold, H. Z. Elektrochem. 1940, 46, 120.

31. Lingane, J. J. Chem. Rev. 1941, 29, 1.

32. Rossoti, F.J.C.; Rossoti, H. The Determination of Stability Constants. Mc Graw Hill, London, 1961.

FAPESP helped in meeting the publication costs of this article 